\title{
Fotballkamp paa Grus og Græs i Kristiania $^{1}$
}

\section{Af Frode Fretland}

»Skaf en grasbane, saa vil Noreg om faa aar slaa baade Danmark og Sverige u uttalte den danske toppdommaren og noregsvennen doktor Hagbart Vestergaard til ein avisjournalist på ein dommarkongress i Kristiania i $1917 .{ }^{2}$ I perioden frå den fyrste landskampen i 1908 og fram til 1917 hadde nordmennene aldri vunne over dei to nabolanda i fotball. Vestergaard viste retorisk at han hadde fått rett $i$ sine spådommar då han tre år seinare uttalte til tidsskriftet Idratsliv: »... Norge har faat en grasbane $i$ Kristiania, og baade Danmark og Sverige har faat nederlagets smerte at føle «. ${ }^{3}$

Baneproblematikk har alltid vore eit sentralt tema i norsk fotballs historie. Vanskeleg topografi og eit barskt klima har vorte nytta som forklaringar på at det har vore få gode fotballbaner rundt om i det ganske land. Dårlege banetilhøve har så vorte nytta som forklaring på at Noreg har hatt problem med å hevda seg i denne sporten. Særleg for fotballeiarar som har vore opptekne av å utvikla gode prestasjonar og konkurrera på ein internasjonal arena har dette vore problemstillingar som har vore viktige heilt frå starten. At København fekk »Idrætsparken« i 1911 og Stockholm »Olympiastadion « i 1912 var til misunning, men og til inspirasjon for fotballelskande nordmenn. »Hvor blir Norge av? « uttalte presidenten i Norges Fotballforbund i 1911 og viste til at her var det ingen sentral idrettsstadion. Sjølv om Noreg fekk ein sentral idrettsstadion i 1914, Frogner stadion i Kristiania med plass til over 15.000 tilskodarar, var det noko som mangla. Underlaget for fotball var grus, og ikkje som i nabolanda, grasdekke. Den fyrste grasbana i Noreg kom ikkje før i 1917 i Stavanger. Året etter kunne klubbane frå Kristiania spela på gras.

Det er ikkje berre det sportslege fokuset som kjem til uttrykk når ein studerar baneproblematikken i Noreg i eit historisk perspektiv. Her var og ein sosial dimensjon. Som Matti Goksøyr og Finn Olstad skreiv det i Norges Fotballforbund si 100 års jubileumsbok: »Fotballbanen ble, ved siden av kirken og kanskje et postkontor, selve kjennemerket på et tettsted og et samfunn «. ${ }^{4}$ I lokal samanheng kom bygging av fotballbaner mange stadar på den politiske dagsorden tidleg på 1900-talet. For at fotballrørsla skulle utvikla seg var dette viktig. Banene var den lokale samlingsplassen for fotball og slik sett avgjerande for fotballens vekst.

I denne artikkelen skal vi gå litt i djupna på dette problemkomplekset og ta føre oss fotballen si utvikling i den norske hovudstaden Kristiania i tidleg periode (ca 19001922) med særleg fokus på baner. Den fyrste tida kan ein snakka om at den lokale og nasjonale fotballutviklinga var to sider av same sak. Det var i Kristiania den organiserte fotballen i Noreg fyrst slo rot og byen fekk raskt nasjonal hegemoni på fotball- 


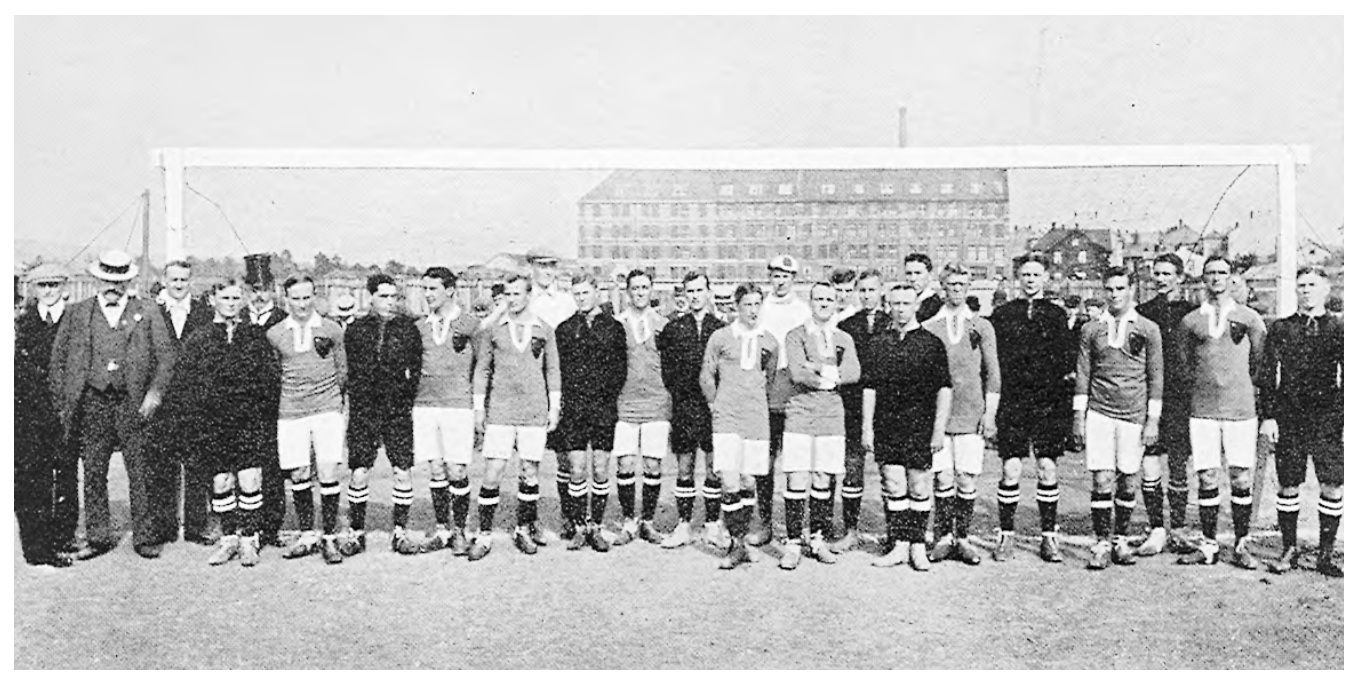

Bilde av det norske og det svenske landslaget frå den fyrste landskampen på norsk grus $i$ 1910. Kampen vart spela på Gamle Frogner Stadion. Svenskane (i mørke drakter) vann kampen 4-0 (Kjelde: Juve Jørgen: Alt om fotball).

bana. Ved å studera den lokale utviklinga i denne byen er det muleg å koma litt i djupna på baneproblematikken og synleggjera fotballens mange utfordringar i ein innleiande fase. To sentrale aspekt ved fotball, den sportslege utviklinga og den samfunnsmessige nytteverdien vert presentert og drøfta i eit lokalt perspektiv.

\section{Starten}

Fotballen som vart spreidd frå England og nådde Noreg i 1885 etablerte seg som ein organisert masseidrett i Kristiania tidleg på 1900-talet. Hovudstaden skulle raskt få ei sentral rolle i utviklinga av fotballsporten, og dominansen i nasjonal samanheng var særleg tydeleg fram til ca 1920. Danninga av Norsk Fodboldforbund i 1902 og Kristiania og Omegns Fodboldkreds i 1905 var viktige milepælar som gav grunnlag for den internasjonale, nasjonale og lokale forankringa til fotballspelet i Kristiania. Bygging av fire stadiona (grusbaner) og ei grasbane (utanfor bygrensa) med nasjonale mål for fotballspel i perioden 1902-1922, var og av avgjerande verdi for fotballveksten i byen.

Fotball, som heilt fram til 1970-åra fyrst og fremst var ein idrett for gutar og unge menn, møtte ein del motstand i tidleg fase. Det kunne vera farleg og føra med seg alvorlege skadar meinte somme. Som signaturen Nero skreiv det i Norsk Idratsblad i 1894: „Jeg har seet ben søndertraadte og afspande, som om de skulde varet trcepinder og jeg har seet, at man har baaret kvaestede legemer bort frå spillepladsen «. ${ }^{5}$ Men spelet fekk etter kvart aksept og vart respektert som positiv ungdomsaktivitet. Innan idrettsrørsla, men og blant pedagogiske og militære autoritetspersonar vart det argumentert for at fotball var ein særs sunn friluftsleik for barn og unge så lenge den var driven fornuftig. Det var få innrapporterte skadar og spelet engasjerte ungdomen. ${ }^{6}$

Den uorganiserte fotballen var ein viktig del av den totale aktiviteten. Der kunne dei 
unge konkurrera etter eigne reglar og tilpassa spelet etter banetilhøve og kor mange som var med. Slik aktivitet gav læring og sosialisering til spelet som var avgjerande for den vidare veksten av organisert fotball. I 1907 konkluderte fotballforbundet sin president i sin gjennomgang av fotballens utvikling at det var nær samanheng mellom uorganisert og organisert fotball: »I alle byer, hvor der findes en organisert klub findes der ogsaa som regel en masse gutteklubber, ja, i større byer skal der findes en i anhver gade «. ${ }^{7}$ Guteklubbane (eller den uorganiserte fotballen) var sjølve grunnlaget for dei organiserte klubbane.

\section{Fotballøkker og Fotballbaner}

Eit grunnleggjande spørsmål kan vera: Korleis var banetilhøva i fotballens barndom i Kristiania? I fotballens heimland, England, var sporten ein vinteraktivitet som vart praktisert på grasbaner. I det høge nord, med eit klima prega av kulde, regn og snø meir enn halve året, var det naturstridig å byggja fotballbaner av gras. Fotball var ein stor sommaridrett i Noreg som tidleg på 1900-talet vart utøvd på forskjellig underlag, men sjeldan på gode grasbaner. Den uorganiserte fotballen vart utøvd på fotballøkker, medan den organiserte delen etter kvart fekk trenings- og kamptid på fotballbaner, som regel med grusunderlag.

Korleis såg ei fotballøkke ut? Her kan ein ikkje vera eintydig, men i denne konteksten var det plassar rundt om i hovudstaden der barn og unge kunne sparka fotball. Dei opphavlege løkkene, her forstått som ubygde tomteareal, ${ }^{8}$ fantes i fleire strøk av byen. Desse områda som lenge hadde vore populære plassar for idrett og leik, var frå starten av viktig for fotballveksten blant barn og unge i Kristiania.
Underlaget kunne vera både grus, stein, mold eller gras og ofte ei blanding. Noko standard eksisterte ikkje. Løkkefotball hadde ei anna tyding enn organisert fotball. Aktiviteten på løkka følgde ikkje same standardkrava som fotballspel i organisert form. Fotballøkkene var særleg knytt opp mot lokal identitet og dermed den sosiale dimensjonen ved fotballspelet. Når Norsk Idrætsliv i 1905 skreiv: »Paa hver liden lфkke eller plads [i Kristiania] sees nu fodboldspillende partier, og interessen for denne udviklende sportsleg er stadig starkt voxende «, ${ }^{9}$ var det nettopp mynta på at fotball hadde lokal forankring fleire stadar i byen.

For den organiserte fotballen var det avgjerande for veksten å få store baner som i alle fall følgde minstestandardmål slik dei var skissert $\mathrm{i}$ fotballreglane for the association football. ${ }^{10}$ Desse minstemåla var »arva« frå England og hadde heile tida vore ein del av regelgrunnlaget for sjølve fotballspelet. I 1901 gjaldt desse standardmåla for fotballklubben Start frå Kristiania:« Fotballpladsens stфrrelse skal vare: laengde hфist $200 \mathrm{~m}$, mindst $100 \mathrm{~m}$, bredde hфist $100 \mathrm{~m}$, mindst $50 m \ll .{ }^{11} \AA$ A byggje slike fotballbaner kravde relativt stort disponibelt areal, noko det var lite av sentralt i Kristiania. Dermed var det naturleg at fotballfolket søkte seg ut av eller i randsonene av byen.

$\AA$ ha lite tilgjengeleg areal for banebygging var ikkje eineståande for Kristiania. I København var det og på tilsvarande vis i randsonene av byen det vart spela fotball. Etter kvart som innbyggartalet auka og fellesområde sentralt i byen minka, vart den såkalla »Falleden«; eit stort grasbelagt område rundt byen, særleg eigna for fotballspel. Det var og her den kjende fotballstadion »Idratsparken « seinare vart bygd. ${ }^{12}$

Lover og reglar for fotball var i sin tidlege barndom ved hundreårsskiftet og pre- 




Viktige standardmål for ei fotballbane i 1910 presentert av Hans Hegna i si bok Friluftslek.

Fig. 13. Plan av spillepladsen.

( $\times$ Straffésparkmerket).

ga av tilfeldigheitar. Auka byråkratisering gjorde det lettare å spreie dei standardiserte reglane for fotballspel. Dei norske oversettingane var kopiar frå England eller Danmark. Norsk Fodboldforbund gav i åra etter danninga i 1902 nærmast årleg ut nye og reviderte utgåver for »love og spilleregler $\ll{ }^{13}$ Presisjonsnivået vart betre for kvar ny utgåve. Men det var ikkje berre fotballforbundet som spreidde kunnskap om fotballreglar. I 1903 gav lærar og gymnastikkinspektør Hans Hegna ut ei bok om friluftslek inkludert ein inngåande gjennomgang av fotballreglane. Der var til dømes 120x80 meter gitt som standardmål for ei fotballbane, men for barn kunne plassen vera mindre. ${ }^{14}$ Banene skulle helst vera ein grasvoll »bl.a.fordi den ikke sliter saa fort paa ballen«, skreiv Hegna.

I 1910 gav Hans Hegna ut andre utgåve av Friluftslek. I følgje den utgåva skulle standard storleik på ei fotballbane vera 100-110 meter lang og 64-73 meter brei. For barn meinte likevel Hegna at øvingsplassar på 80x45 meter måtte vera brukandes. I figuren over ser ein at banemerkinga i 1910 ikkje var så heilt ulikt dagens mål for korleis ei fotballbane skal sjå ut.

Standardmål var berre viktig på papiret. I praksis var det få eller ingen fotballbaner 


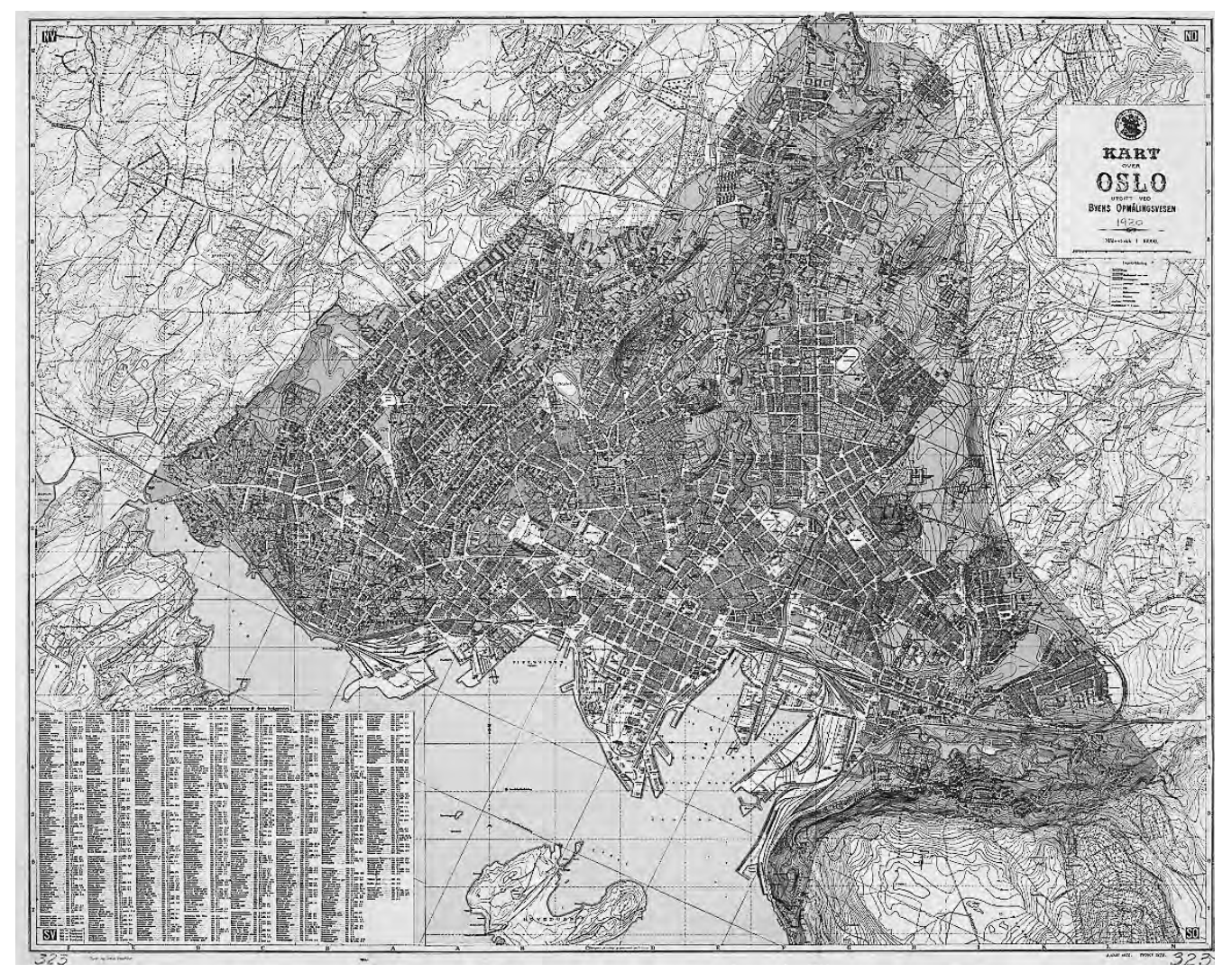

Kart over Kristiania 1920 (Eigar: Oslo kommune, plan og bygningsetaten).

som hadde minstemål i den tidlege fasen og dei aller fleste løkkene og øvingsplassane var småe, men likevel utgangspunkt for aktivitet og klubbdanning. Før me går vidare er det eit poeng å understreka at det var den internasjonale standarden som var utgangspunkt for argumentasjonen til fotballfolket i Noreg. Skulle ein få fotballutvikling ut over den lokale nivået måtte det byggast betre fotballbaner.

\section{Geografisk og sosial spreiing av fotballspelet}

Den geografiske og sosiale spreiing for den organiserte fotballen i Kristiania heng saman. I perioden 1902-1912/13 var organisert fotball fyrst og fremst ein borgarleg aktivitet for gutar og unge menn på vestkanten av byen. I den neste perioden, frå 1912/13 til ca 1922 vart lag frå arbeidarstrøk på austkanten av byen ei dominerande kraft i den organiserte fotballen. ${ }^{15} \mathrm{Om}$ ein ser på tilgjengelege fotballbaner aust og vest i byen kan dette vera med å gje ei forståing av utviklinga. I den fyrste perioden (1902-1912/13) vart det bygd to baner på vestkanten (Frogner 1902 og Bislett 1907) og ingen i aust, medan det i den andre perioden vart bygd to baner på austkanten (Dælenenga 1916 og Jordal 1922) og ingen $i$ vest.

Baneanalogien forklarar likevel ikkje 


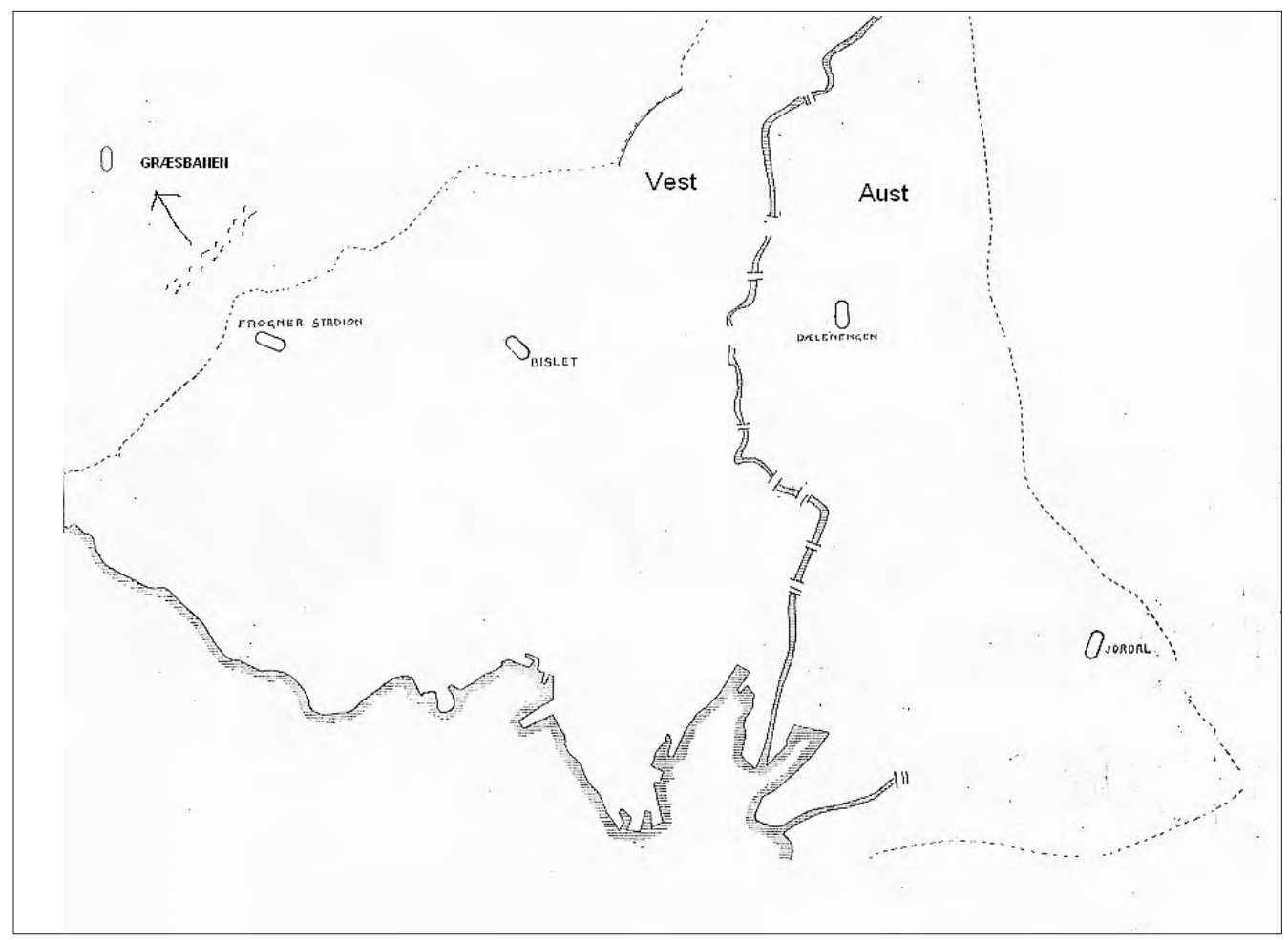

Rammekart over Kristiania ca 1920 med innteikna stadionar for fotball. Byen blir delt $i$ vest og aust av Akerselva (Kjelde: Dokument nr 19 (1919-1920) Indstilling fra det kommunale Idratsutvalg om anlag, utstyr, bruk og tilsyn av leke-, фvelses og idratspladser $i$ Kristiania, Aktstykker Kristiania kommune).

alt. Mange prosessar gikk parallelt. I Kristiania by var det i denne perioden store sosiale endringar der betre butilhøve, betre kommunikasjon og betre kommunal tilrettelegging på fritida var viktige utviklingstrekk for innbyggarane. Nye områder i randsoner rundt sentrum vart bygd ut, og sjølv om innbyggjartalet ikkje auka så mykje i perioden (frå 242.113 i 1910 til 260.817 i $1920^{16}$ ) var det særleg auke i folketalet aust og nord i byen. Generelt betre levevilkår, meir fritid og endra alderssamansetning; Kristiania hadde i 1920 større preg av ungdomsby enn nokon gong, ${ }^{17}$ skapte godt grunnlag for fleire fotballklubbar i byen.
Sosialdemokratisk påverknad og auka offentleg engasjement

Det politiske landskapet var i ferd med å endra seg på 1910-talet. Partipolitiseringa, der Høgre og Arbeidarpartiet etter kvart vart dei store blokkene, vart tydlegare. Kampen mellom Høgre og Arbeidarpartiet hadde og geografiske implikasjonar. Høgre dominerte på vestkanten og Arbeidarpartiet hadde flest velgara aust i byen. Etter ein langt periode med Høgre ved det kommunale roret (frå 1899-1916) fekk Arbeidarpartiet etter kvart større oppslutning og sat med ordføraren i 1917-19. ${ }^{18}$ Fram mot det 
moderne Oslo (frå 1925) var det tydeleg at eit meir sosialdemokratisk andedrag tok opp konkurransen med den tidlegare konservative praksisen som mange prosessar i byen var prega av, mellom anna knytt til fritid og idrett. Sjølv om det fyrst var i mellomkrigstida at politiseringa vart tydeleg $\mathrm{i}$ idretten, hadde dette og konsekvensar i denne perioden. Det vart meir aksept for at kommunen hadde ansvar for å tilrettelegga for fysisk aktivitet blant barn og unge.

På tilsvarande måte var det i Danmark. Den fyrste sosialdemokratiske borgarmeistaren i København, Jens Jensen, sørgde for tilrettelegging for »play and sport« på »Falleden « for byens folk. ${ }^{19}$ På dette området vart det bygd 12 fotballbaner og ein stadion (Idrætsparken) som etter kvart skulle bli eit viktig grunnlag for dansk hegemoni på fotballbana. Bakgrunnen for det kommunale engasjementet var mellom anna at dei ikkje-bane eigande klubbane, t.d. arbeidarklubbane, skulle få eit område med oppmerka fotballbaner inkludert mål, corner flagg og liknande, som var godt eiga til å driva med konkurransefotball. Dette var lagt merke til i andre land og den norske fotballpresidenten brukte i 1911 mellom anna Danmark og bygginga av »Idratsparken« som eit mønster Noreg burde følgje. ${ }^{20}$

I Sverige finnest det og døme på at sosialdemokratisk maktovertaking har hatt positive konsekvensar for bygging av fotballbaner i tidleg periode. Torbjörn Andersson har vist at »den nya idrottsplatsen $i$ Landskrona omöljligen kunnat tilkomma utan sosialdemokratien «. ${ }^{21}$ Det sosialdemokratiske partiet overtok makta i staden 1919 og ny stadion vart opna i 1924. Økonomisk støtte frå stat og kommune var avgjerande for at ein av dei mest moderne og største idrettsanlegg i Sverige på den tid vart bygd i Landskrona. Ordføraren og

Tabell 1: Antall personar som nytta seg av offentlege idrettsanlegg i Kristiania/Oslo i perioden 1905-1920

1905

1910

1920

Kjelde: Beretning om Oslo kommune for årene 1912-1947, bind I, s. 275.

riksdagsmannen Ola $\mathrm{H}$ Waldén understre$\mathrm{ka}$ at anlegget »ej er någon privategendom ${ }^{22}$ På tilsvarande måte som i København og i Kristiania var bygginga av offentleg idrettsplass i Landskrona kopla direkte opp mot den veksande arbeidarklassa.

Meir generelt kan ein seia at perioden 1893-1919 er blitt framstilt som ei veksttid for norsk idrett. ${ }^{23}$ Auka offentleg engasjement var ein del av utviklinga. Fotballen si utvikling i Kristiania passar dermed inn i totalbildet av utviklinga i idretten. Veksten i norsk idrett var spesielt stor i perioden 1914-1918. ${ }^{24}$ Det var i same periode som fotballen i Kristiania tok av.

Lokalt kan ein og få eit godt inntrykk av veksten. Berre det at Kristiania kommune frå 1911 hadde eit fast utval for idrettssaker, og frå 1916 eigen administrasjon for idrettsvesenet underlagt vegvesenet, viser kommunalt engasjement. Idrettsvesenet var særleg sentrale $\mathrm{i}$ anleggsutbygginga $\mathrm{i}$ byen. Eit overordna mål var å få mange aktive, særleg barn og unge. I ein kort historisk gjennomgang av idrettsvesenet og kommunen sitt arbeid for idrett kom det fram at veksten blant aktive »trenende« $\mathrm{i}$ perioden 1905-1920 var stor. ${ }^{25}$ Særleg var veksten stor mellom 1910 og 1920. Tabellen over gir eit bilde på kor mykje idrettsbanene i hovudstaden var i bruk.

Ein bør nok vera kritisk til tala og omgrepsbruken. I 1920 var det 260.817 inn- 
byggarar i Kristiania og dermed måtte i praksis altså nesten halvparten av folka vore aktive ved offentlege anlegg. Det er lite truleg. Mest sannsynleg var det mange som trena meir enn ein gong og tala viser dermed kor mykje dei offentlege anlegga vart brukt. Likevel viser det ein tendens. Registrert aktivitet på offentlege baner gjekk drastisk opp. Fotball var ein viktig del av denne aktiviteten. Med utgangspunkt i den svenske forskaren Olof Moen sitt arbeid kan ein hevda at talet på aktive »trenende « var eit viktig suksesskriterium som kunne vera med å legitimera det kommunale engasjementet i bygginga av fotballbaner. ${ }^{26}$

Offentleg engasjement vart tydlegare i slutten av denne perioden. I 1917 fekk idrettsutvalet i oppdrag av formannskapet å utarbeide "planer og forslag til istandbringelse av leke-, $\phi v e l s e s$ og idratsplad$s e r \ll{ }^{27}$ i Kristiania. To år etter fekk formannskapet $\mathrm{i}$ byen innstillinga på bordet. I »Indstilling fra det kommunale idratsutvalg om ... фvelses- og idrcetspladser i Kristiania « frå 1919-20 vart det argumentert for at ungdomen burde få tilfredstilt sin »bevagelsestrang under fuld tilgang av lys og luft «. ${ }^{28}$ Innstillinga var rask med å peike på at idrettsanlegg ikkje fyrst og fremst skulle byggast for å leggja til rette for »maksimalprastationer foran velbesatte tilskuerbanker «. Det var nytteverdien som var interessant:

"Det egentlige maal - det som er knyttet til virkelige samfundsbehov - er at aapne adgang til den jovne frilufts $\phi v e l s e$ for al ungdom, og helst den del som er henvist til de trangeste kvartaler ${ }^{29}$

Argumenta dreidde seg om helse og oppdraging av den oppveksande slekt, med særleg fokus på den veksande arbeidarklassa. Deltaking i idrett og »frilufts- $\emptyset$ velse « kunne vera botemiddel for mange under byens uheldige oppvekstvilkår der store familiar måtte bu i tronge, lysfattige leilegheiter og barna just hadde bakgarden som leikeplass.

Kommune var oppteken av å leggja til rette for at ungdomen kunne driva med fysisk aktivitet, men kor viktig var det å få bygd gode baner? I kor stor grad vart banen bygd med utgangspunkt i fotballen sine standardkrav? Innstillinga frå det kommunale idrettsutvalet skapte debatt og sentrale fotballeiarar var på ingen måte nøgd med rapporten.

\section{Idrett som samfunnsnytte eller idrett som konkurranse}

I 1919 kommenterte fotballforbundet sin sekretær Peder Christian Andersen instillinga til det kommunale idrettsutvalet $\mathrm{i}$ idrettsbladet Idratsliv. Han var misnøgd. For det fyrste hadde komiteen feil samansetning. Den burde supplerast med sakkyndige menn meinte Andersen. Særleg menn som hadde greie på fotballbaner. Innlegget var delvis eit personangrep på Hans Hegna som hadde skrive rapporten. Sidan Hegna kunne koma med argument i høve utbygging av store fotballbaner av typen: »har det litet å si om banerne mangler nogen meter $i$ maal som kreves $i$ internationale stevner «, vart han rekna som inkompetent av Andersen. Hegna kunne ikkje vera rette mann for Kristiania kommune for å yte sakkyndig vurdering:

»Hans idratsbegreper er praget av lacgmandssystemet og hva verre er, han er tilhanger av den retning som staar uforstaaende overfor idrattens idé og aand. Han er ikke àjour med utviklingen, kan ikke tanke og fole med idrats- 
mandene og vet derfor ikke hvor skoen trykker . $^{30}$

P.Chr. Andersen var ikkje heilt etterretteleg og kritikken mot Hegna var ikkje heilt rettferdig. I dokumentet frå Idrettsutvalet sto det i høve saken som er nemn ovanfor: »Samfundsmassig set har det litet at si om ungdommens frilufts $\phi$ velser foregaar paa baner som mangler nogen meter af de internationale maal eller ikke ${ }^{31}$ og konklusjonen på resonnementet var at byen trengde fleire små øvingsplassar. Om ein hoppar fram til notid er alle dei nye balløkkene (eller ballbingar som det heiter i dag) rundt om i Noreg kanskje eit bevis på at Hegna sine tankar ikkje var så dumme. Å få bygd mange små inngjerda øvingsplassar i lokalsamfunna rundt om i landet er i dag eit viktig idrettspolitisk mål. Ballbingane skal vera godt eigna som ei trygg »leikegrind « for barn og unge, men i tillegg og vera eit anlegg som gjev grunnlag for å utvikla god fotballferdigheit. ${ }^{32}$ Sjølv i 1919 meinte Hegna at han hadde sine ord i behald: $\gg-j a$ det er virkelig autoriteter som mener at f.eks. fotbalspill for gutter av de yngre aarsklasser kun bør фves paa mindre baner «. ${ }^{33}$

P. Chr. Andersen og fotballforbundet var ikkje tilhengarar av små baner. Skulle det vera av interesse for fotballungdomen måtte det $\mathrm{i}$ alle fall tilfredstilla reglane for minstemål på fotballkampar (11 mot 11). Dette minstemålet var 45x90 meter. I innstillinga frå det kommunale idrettsutvalet vart det skissert mange småbaner av storleik 7080x30-40meter. P.Chr. Andersen var oppteken av at de måtte byggjast store baner, slik som Frogner, Bislett, Dælenenga og Jordal.

Kommentarane i høve instillinga var nok eit utslag av frustrasjon fordi dei kommunale myndigheitene ikkje i stor nok grad forsto at idrettskonkurransen måtte takast på alvor. Eit sentralt aspekt ved fotballspelet var knytt til eigenverdien; gleda ved å spela fotball, gleda ved å konkurrera, og ikkje primært til samfunnsnytten. Då måtte banene vera av rett storleik, elles kunne dei ikkje nytast til seriøs konkurranseaktivitet. Helst ville fotballfolket i Kristiania ha grasbaner.

\section{Lengten etter grasbane}

I ein bykamp i juni 1914 spela Göteborg uavgjort 2-2 mot bylaget til Kristiania i Sverige. Norsk idrætsblad hevda i referatet at kampen var eit steg i rett retning, og det skulle lova godt for »fotballsporten her hjemme«. Framgangen var likevel avhengig av at det vart bygd baner: »Naar vi nu bare kommer saa langt at vi faar grasbaner, skulde vi vel snart haa haap om seir over utenlandske lag vi ogsaa! «. ${ }^{34}$ Tilsvarande tankar kom fram etter at det norske landslaget hadde tapt 0-7 mot Sverige i Sverige seinare på hausten.

Sportsleg sett var det frustrerande at hovudstaden ikkje hadde grasbane. Sjølv om Noreg og Kristiania i 1914 hadde fått ei flott fotballbane på ein nybygd Frogner Stadion, var det ein vesentleg ting som ikkje var bra nok Banedekke var av grus. I 1915 måtte kretsstyret takka nei til eit forslag frå Sverige om å oppretta ein nordisk byserie. Grunngjevinga var dårlege banetilhøve i Kristiania. ${ }^{35}$ Bakom låg nok og frykta for dårlege resultat på utebane. Spelarane frå Kristiania kunne ikkje trena eller spela kampar på gras, og ville vore dårleg rusta $\mathrm{i}$ ein slik serie. Men tre år seinare skulle tilhøva endra seg. Hausten 1918 vart Grcesbanen opna: »Det utrolige er skedd«: Vor grasbane er dopt og indviet «. ${ }^{36}$

Eit samarbeidsprosjekt mellom dei to Kristiania-klubbane Mercantile og Ready hadde ført til den fyrste grasbana for klub- 
bane i Kristiania. Ei sentral utfordring var likevel tilstades. Bana låg langt utanfor sentrum, på Vestre Holmen vest for Kristiania i nabokommunen Aker. Dette medførte store reiseavstandar både for publikum og aktive. Dei to baneeigande klubbane Mercantile og Ready valde til dømes eitt år etter opninga (4. juni 1919) å spela innbyrdes kamp på grusen på Frogner Stadion, trass i mulegheit til gras på Græsbanen. Kommentaren i Norsk Idrettsblad var klar og eintydig: »Det er nok saa, at det er langt avgaarde til Grasbanen, isaer falder veien tung naar sol staar og steker intens men banen burde vel forst og femst brukes av sine egne. « ${ }^{37}$ Publikum var heller ikkje van med å måtte reisa langt utafor sentrum for å sjå fotballkampar.

»Alt skal indarbeides, det merker man tydelig paa besфket paa Grasbanen $i$ pinsedagene. Tiltrods for den vakre bane og de respektable fotballnavn som »Brann« og »Sarpsborg", var likevel bes $\phi k e t$ temmeleg tyndt. Folk har endu ikkje faat det $i$ sig at man kan se god fotball utenfor [Frogner] Stadion $\ll^{38}$

Græsbanen fekk likevel ein sentral posisjon. Bana gav gode treningstilhøve for dei beste i Kristiania. I 1919 slo Noreg Sverige både borte og heime, og Danmark heime. Heimekampane gjekk på Græsbanen, og fleirtalet av spelarane kom frå lag i Kristiania og Omegns Fodboldkreds. ${ }^{39}$ Etter svenskekampen kunne Norsk Idrotsblad og Sport meddele: »Grasbanen besto sin store prove med glans og det er med glade dette konstanteres. Det vakre gronne teppe og den lune beliggenhet bidrar sit til at gjøre en kamp deroppe festlig." Grasbanen hadde overteke hegemoniet frå Frogner Stadion for den store fotballopplevinga.
Snart etter opninga vart anlegget på Vestre Holmen sett på som naturleg landskamparena. I perioden 1919-1926 vart alle heimekampane for landslaget, så nær som to, spela på Græsbanen. Etter kvart vart det nok gjævare både å trena og spela på gras, og publikum møtte opp for å sjå på. Under ein bykamp mellom Kristiania og Göteborg hausten 1920 var 8.000 tilskodarar tilstades $\mathrm{i}$ det fine været, og $\mathrm{i}$ finalen $\mathrm{i}$ Noregsmeisterskapen same år opp mot det dobbelte. »Kongen og kronprinsen var tilstede og blev hilset med kongesangen «. ${ }^{40}$ Den nasjonale dimensjonen var tydeleg.

\section{Avslutning}

I 100-års jubileumsboka til Norges Fotballforbund omtalar forfattarane Matti Goksøyr og Finn Olstad norsk fotball si utvikling fram til 1920-åra som særleg prega av idealet om borgarleg danning. Fotballen vaks inn i »det samfunnsmessige maktfeltet, som del av borgerlige grupperingers krav på sosial hegemoni og kulturell dominans $«{ }^{41}$ Fotballbanene var fotballen sin materielle basis. Då fotballinteressa vaks og nye fotballklubbar vart ei tydeleg trekk i byutviklinga i Kristiania på 1910talet var dette ei kulturell endring som måtte få konsekvensar for utnytting av byrommet. Men fotballens folk hadde det ikkje enkelt. Då bygging av fotballbaner kom på dagsorden måtte dei »kjempe om ledige arealer med interesser som vanligvis var $\phi k o n o m i s k$ tyngre og sosialt «viktigere»«. ${ }^{42}$

Denne artikkelen, som har eit lokalt utgangspunkt, viser at det var mange prosjekt som var på gang i norsk fotball i perioden fram mot 1920. Eit sentralt prosjekt for fotballen sine representantar var å få til gode fotballag i Kristiania. Då måtte det byggast gode grasbaner. Det gav gode resultat for både landslag og bylag og auka 
entusiasme blant spelarar, leiarar og publikum. Noreg kunne hevda seg og kjempa på den internasjonale arenaen. Men for fotballen sine folk var og fotballen si totale utvikling viktig. Kort oppsummert kan ein snakka om fokus både på topp og breidde. For å auka prestasjonsnivået måtte det byggast baner som var kvalitativt bra, altså grasbaner, men samtidig måtte ein ha baner som kunne ta i mot den store veksten. Det vil seia slitesterke og tålte stort bruk, i praksis altså grusbaner. Problemet var økonomisk kapital. Korkje forbund eller krets hadde økonomi til å byggja anlegg. Fotballfolket vart dermed totalt avhengig av kommunal velvilje og privat initiativ. Den kommunale velviljen var tilstades, men ikkje når det gjaldt å tilfredstilla fotballfolket sine ynskjer om grasbaner. Då måtte det privat initiativ til. Den fyrste grasbana vart bygd på vestkanten utafor bygrensa med privat kapital i ryggen. Ein av konsekvensane var at mange lag (særleg på austkanten av byen) var utelukka frå dei gode banetilhøva. Den sportslege fokus hadde dermed sosiale og geografiske implikasjonar.

Men fotballsporten hadde og potensiale i seg til å bli eit sosialt prosjekt, eller sagt på ein annan måte: å bli nytta i ein større sosial samanheng. Om det offentlege (dvs: kommunale myndigheiter) skulle gå inn å kosta bygging og drift av idrettsanlegg måtte aktiviteten legitimerast. Det mest sentrale argumentet i så måte var at idrett var samfunnsnyttig, særleg med omsyn på den oppveksande slekt. I perioden 19051907 leia til dømes tidlegare nemnde Hans Hegna eit fors $\varnothing$ ksprosjekt med friluftsleik i sommarferien sett i gang av Kristiania kommune. Prosjektet var ein del av det som Hegna kalla »det offentleg oppdragelsesarbeide« og kunne koplast opp mot

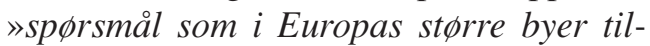

lagges stadig voksende betydning «. ${ }^{43}$ Det vil seia større fokus på å få barn og unge til å vera meir fysisk aktive og ute i friluft. På tilsvarande måte argumenterte det kommunale idrettsutvalet i Kristiania (med Hans Hegna spissen) i 1919 for at bygging av anlegg til idrett for barn og unge måtte ha som hovudmål å tilfredstille »ungdommens trang til bevagelse «. ${ }^{44}$

Fotballen sin nytteverdi vart enno tydlegare i mellomkrigstida. Fotballbana vart ein viktig møteplass og arena for både unge og vaksne i den framveksande arbeidarklassa. I eit jubileumsskrift for arbeideridrettslaget Vika IL viste kommunisten Olaf Thorsen (sekretær for Arbeidernes idrettsopposisjon i 1921) kor viktig det var for arbeidarungdomen å delta i fotballkampar mot lag frå andre delar av byen:

»Fotballspillet sto hoyt i kurs ... Fotballspillerne skulle på trening utenfor Vika. De kom til fremmede folk og steder, og ville gjerne hevde seg på alle mulige maiter. Garderobeforholdene var ofte svaert enkle, og det man hadde av klaer og utstyr kom til à ligge synlig for hvem som helst. Dette forte med seg at gutta ville vise seg i rene, hele klor. Det skaffet hjemmene mye ekstraarbeid, delvis også utgifter, og kravene steg stadig til properhet, orden, penere og bedre utstyr. Deltakelse i kamper forde gutta vidt omkring. De mottok mange inntrykk og hadde mye å fortelle om når de kom hjem $\ll .{ }^{45}$

Slik kan fotball forståast som ein nytteidrett som kunne forsvarast av ulike samfunnsinteresser fordi den skjedde ut i friluft, fordi den engasjerte ungdomen, fordi den var lett å organisera, den kunne vera dannande, og den var ufarleg for helsa om den vart utøvd i kontrollerte former. Fot- 


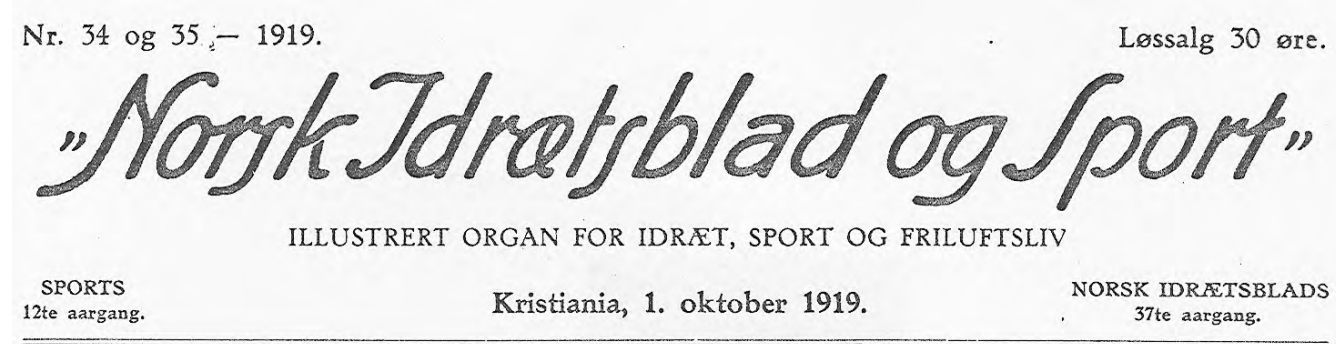

Obs.l Eftertryk av artiklet og illustrationer uten nuiagtig kildeangivelse er forbud! !

Da Norge slog Danmark $\mathbf{i}$ fotball. Av cand. jur. Chr. Erlandsen.

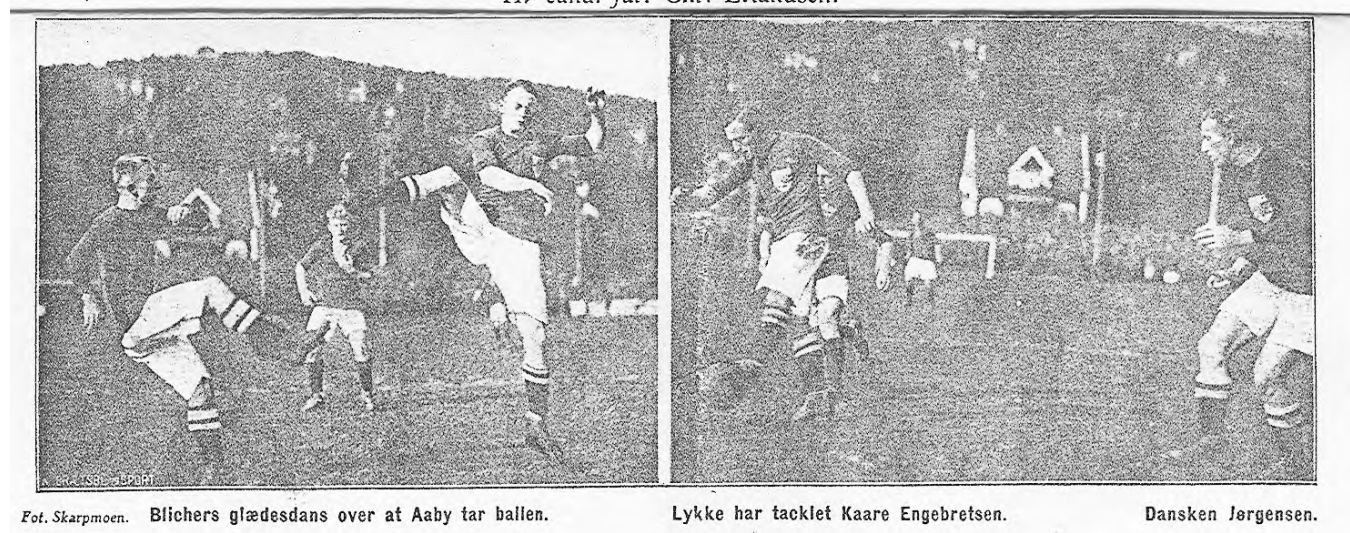

Reportasje $i$ norsk tidsskrift etter at Noreg hadde slått Danmark 3-2 på Grasbanen $i$ 1919.

ballbanene vart ein viktig møteplass for barn og unge. Men det viktigaste for fotballfolket i 1919 var kanskje når alt kom til alt, at det norske landslaget hadde sigra over Danmark og Sverige på norsk gras!

\section{Noter}

1. Overskrifta er inspirert av boka med tittelen »Fotballkamp paa grus og græs i 25 aar « av Arvid Skappel. Kristiania var det gamle namnet på byen som i dag heiter Oslo. Namneskiftet skjedde 1. januar 1925.

2. Idrætsliv 28.6.1920.

3. Idrætsliv 28.6.1920.

4. Goksøyr M og Olstad F. Fotball! (Oslo, 2002), p. 195.

5. Norsk Idrætsblad nr. 81894.
6. Den norske fellesorganisasjonen for Idrett, »Centralforeningen for udbredelse af idræe « støtta fotballforbundet sin aktivitet ved å gi premiar. Ein premiss var at fotballspelet ikkje utvikla seg i negativ og voldeleg retning slik mange meinte det hadde gjort både i Amerika og delvis England. Dermed var det og viktig for fotballforbundet å vise at deltaking i spelet ikkje medførte særleg stor riskiko for skade. Sjå til dømes Norsk Idrætsblad nr. 221906 og årsrapport frå Norsk Fodbold- 
forbund i Centralforeningen for udbredelse af idræt, aarsberetning for 1906, p. 75 ff, spesielt p. 80.

7. Norsk Idrætsblad nr. 441907.

8. Sjå til dømes Oslo Byleksikon, 4. utg. ( Oslo 2000), p. 268 og Kjeldstadli K. (Oslo, 1990), p. 427.

9. Norsk Idrætsblad nr. 261905.

10. Utgangspunktet for organisert fotballspel i dei nordiske landa var dei engelske fotballreglane for »association football«, der eit sentralt punkt var at ein ikkje hadde lov til å bruka hendene. Hendene var derimot tillatt å bruka i det andre engelske fotballspelet som vart kalla »rugby football«. Begge fotballspela hadde same røtene, men hadde utvikla seg i ulik retning i andre halvdel av 1800-talet. Sjå meir om dette i Russel D. (1997), p. 17ff.

11. Norsk Idrætsblad nr. 241901.

12. Sjå Toft J. (1995), pp. 59-80.

13. Sjå til dømes faksimile av lovutgåver for Norges Fotballforbund 1902-1907 i Andersen P. Chr. (1927), p. 30.

14. Hegna H. (1903), p. 19.

15. Sjå oversikt over klubbar i Kristiania og Omegns Fotballkrets i perioden 1905-1930 i Andersen P. Chr. (1933), pp. 88-89. Same stad p. 182, fokuserar Andersen på aust-vest skiljet i Kristiania. Meir generelt blir den borgarlege hegemoni og arbeidarklassen sitt inntog på fotballbana handsama i Goksøyr M \& Olstad F. (2002), sjå spesielt p. 43ff, p. $119 \mathrm{f}$ og p. 360.

16. Kjeldstadli K. (1990), p. 54.

17. Ibid, s. 164.

18. Ibid, s. 270.

19. Sjå Toft J. (1995), p. 61ff og Hansen J. (2006), p. $38 f$.

20. Sjå til dømes fotballpresident C. F. B. Schøyen sin artikkel »Av sportens evangelium « i julenummeret av Fotball, det offisielle organet for Norges Fotballforbund, Kristiania 1911.

21. Andersson T. (2002) p. 13.

22. Ibid p. 16.

23. Olstad F. (1986), p. 164-166.

24. Ibid.
25. Beretning for Oslo kommune for årene 19121947 (1952), p.275.

26. Moen O. (1990), p. 9.

27. Dokument nr. 19 (1919-1920) Indstilling fra det kommunale Idrætsutvalg om anlæg, utstyr, bruk og tilsyn av leke-, øvelses og idrætspladser i Kristiania, Aktstykker Kristiania kommune.

28. Ibid.

29. Ibid.

30. Idrætsliv 7.3.1919.

31. Dokument nr. 19 (1919-1920) Indstilling fra det kommunale Idrætsutvalg om anlæg, utstyr, bruk og tilsyn av leke-, Øvelses og idrætspladser i Kristiania, Aktstykker Kristiania kommune.

32. Norges Fotballforbund gir praktisk og $\varnothing$ konomisk støtte til slik bygging, og har klare forventingar om at løkkene skal skapa meir teknisk skulerte norske fotballspelarar i framtida. Forbundet har som uttalt mål at alle skular i Noreg bør ha minst ein ballbinge i skulegarden. Sjå nettsidene til Norges Fotballforbund http://www.fotball.no/ på sidene om anlegg/nærmiljøanlegg/ballbinger (lest 1.12.2006).

33. Dokument nr. 19 (1919-1920) Indstilling fra det kommunale Idrætsutvalg om anlæg, utstyr, bruk og tilsyn av leke-, Øvelses og idrætspladser i Kristiania, Aktstykker Kristiania kommune.

34. Norsk Idrætsblad 17.6.1914.

35. Andersen P. Chr. (1933), p. 60.

36. Norsk Idrætsblad og Sport 4.9.1918.

37. Norsk Idrætsblad og Sport 4.6.1919.

38. Norsk Idrætsblad og Sport 11.6.1919.

39. Fram til 1920 kom nærare $2 / 3$ av dei norske landslagsspelarane frå Kristiania og Omegns Fodboldkreds. Sjå Goksøyr M \& Olstad F. (2002), p. 60.

40. Norsk Idrætsblad og Sport 20/10-1920.

41. Goksøyr M \& Olstad F. (2002), p. 360.

42. Goksøyr M, Andersen E \& Asdal K. (1996), p. 67.

43. Hegna H. (1908), p. 1.

44. Dokument nr. 19 (1919-1920) Indstilling fra det kommunale Idrætsutvalg om anlæg, utstyr, bruk og tilsyn av leke-, øvelses og idrætspladser i Kristiania, Aktstykker Kristiania kommune.

45. Vika Idrettsforening gjennom 30 år (1948) p.16. 


\section{Litteratur}

Andersen P. Chr. Norges Fotballforbund gjennem 25 år (Oslo, 1927).

Andersen P. Chr. Oslo Fotballkrets gjennem 25 år (Oslo, 1933).

Andersson T. Landskrona - Sveriges starkaste fotbollsfäste. I: Idrott, Historia, Samhälle, Svenska idrottshistoriska föreningens årsskrift 2002 (2002).

Beretning for Oslo kommune for årene 1912-1947 (Oslo, 1952).

Fotball (Offisielt organ for Norges Fotballforbund 1911-14).

Goksøyr M. Lange baller mot Nord - om norsk fotball og geografiske utkanter. I: Idrott, Historia, Samhälle. Svenska idrottshistoriska föreningens årsskrift 2002 (2002).

Goksøyr M \& Olstad F. Fotball! Norges Fotballforbund 100 år (Oslo, 2002).

Goksøyr M, Andersen E og Asdal, K. Kropp, kultur og tippekamp (Oslo, 1996).

Hansen J. Fodbold - en kort verdenshistorie (Odense, 2006).

Hegna H. Friluftslek: udvalgte ballspil og andre leker med et tillag om idrat paa fri plads (Kristiania, 1903).

Hegna H. Friluftslek: utvalgte leker og idratsformer for skoler og ungdomslag 2.opl (Kristiania, 1910).

Hegna H. Kristiania kommunes fors $\phi k$ med friluftslek i sommerferien 1905-1906 og 1907. (Kristiania, 1908).
Idratsliv.

Juve J. Alt om Fotball (Oslo, 1934).

Kjeldstadli K. Oslo bys historie bind 4. Den delte byen fra 1900 til 1948, (Oslo, 1990).

Moen O. Idrottsanlänleggningar och idrottens rumsliga utveckling $i$ svensk stadsbyggande under 1900-tallet, (Gøteborg, 1990).

Norsk Idratsblad (Norsk Idratsblad og Sport frå 1915).

Olstad F. Norsk Idretts Historie 1861-1939 (Oslo, 1986).

Oslo Byleksikon, 4. utg. (Oslo, 2000).

Russel D. Football and the English. A Social History of Association Football in England, 1863-1995 (England, 1997).

Skappel A. Fotballkamp paa grus og gras i 25 aar (Christiania u.å.)

Toft J. The Copenhagen Idratsparken: From Democratic Institution to Private Enterprise. I: Bale J \& Moen O. (red.) The Stadium and the City (Staffordshire, England, 1995).

Vika Idrettsforening gjennom 30 år (Oslo, 1948).

\section{Arkiv}

Oslo kommune. Byarkivet.

Dokument nr 19 (1919-1920) Indstilling fra det kommunale Idratsutvalg om anlag, utstyr, bruk og tilsyn av leke-, фvelses og idratspladser i Kristiania, Aktstykker Kristiania kommune. 